\title{
BERBERZY NA MARGINESIE HISTORII
}

BERBERS MARGINALIZED BY HISTORY

Abstract

The Berbers belong to a group of "nations without state." They are divided into a number of factions characterized by their own specificity (dialect and way of life), scattered endemically in Algeria, Morocco, Tunisia, Libya and Egypt (including Tuareg, in Mali, Niger and Mataranka). They all maintain a certain distance to state authorities (especially in Morocco and Algeria), where they are a significant minority, dominated by Arabic-speaking elites.

The total number of Berbers is difficult to ascertain because of the ambiguity of the term "Berber" (which results from different degrees of arabization of Berbers). For centuries they have been Islamic, living in the shadow of the Arab population. Little is known about the significant contribution of Berbers to the development of ancient cultures of the Mediterranean and the first centuries of Christianity.

Despite their linguistic and cultural Arabization (Islamization), they have maintained their distinctiveness. Manipulated by colonial France within the framework of the so-called "Berber policy," they were entangled in conflicts with their Arab counterparts in Algeria and Morocco.

Key words: Berbers; Amazigh; Ibn Chaldun; Arabization; colonialism; Berber policy

RYSZARD MARIA VORBRICH Uniwersytet im. Adama Mickiewicza, Poznań E-mail: vorbrich@amu.edu.pl

CITATION: Vorbrich, R. M. (2018). Berberzy na marginesie historii.

1 Niniejsze opracowanie stanowi pierwszą część studium dotyczącego historii i współczesnych procesów etnicznych obejmujących ten zapoznany lud Afryki Północnej. Kolejne dwie części poświęcone będą rewitalizacji kultury i języka berberyjskiego oraz globalizacji kultury berberyjskiej.

CITATION: Vorbrich, R. M. (2018).
Berberzy na marginesie historii.
Sprawy Narodowościowe. Seria nowa, 2018(50).
https://doi.org/10.11649/sn.1613
This work was supported
by the author's own resources.
No competing interests have been declared.

This is an Open Access article distributed under the terms of the Creative Commons Attribution 3.0 PL License (creativecommons.org/licenses/by/3.0/pl/), which permits redistribution, commercial and non-commercial, provided that the article is properly cited. (C) The Author(s) 2018.

Publisher: Institute of Slavic Studies, Polish Academy of Sciences 
Berberzy należą do „narodów bez państwa”. Dzielą się na szereg odłamów odznaczających się własną specyfiką (dialektem i sposobem życia), rozrzuconych endemicznie na terenach Algierii, Maroka, Tunezji, Libii i Egiptu (a włączając w to Tuaregów, także Mali, Nigru i Mauretanii). Łączy ich utrzymywanie pewnego dystansu do władz państwowych (zwłaszcza Maroka i Algierii), gdzie stanowią znaczącą mniejszość, zdominowanych przez arabskojęzyczne elity.

Ogólna liczba Berberów jest trudna do ustalenia z powodu niejednoznaczności samego terminu „Berber" (co wynika z różnego stopnia zarabizowania Berberów). Od stuleci zislamizowani, żyją w cieniu ludności arabskiej. Mało znany, a warty ukazania, jest wkład Berberów w rozwój kultur antycznych basenu Morza Śródziemnego oraz pierwszych wieków chrześcijaństwa.

Pomimo trwającej stulecia arabizacji językowej i kulturowej (islamizacji) zachowali oni świadomość odrębności. Manipulowani przez kolonialną Francję w ramach tzw. polityki berberyjskiej, zostali oni uwikłani w konflikt ze swymi arabskimi współrodakami w Algierii i Maroku.

Słowa klu czowe: Berberzy; Amazigh; Ibn Chaldun; arabizacja; kolonializm; polityka berberyjska

\section{ROZMYTA ETNOGENEZA}

$\mathrm{B}$ erberzy należą do grona „narodów bez państwa”. Od stuleci zislamizowani, żyją w cieniu ludności arabskiej, która „zalała” ich ojczyznę i zmarginalizowała politycznie i kulturowo. Pragnę przedstawić specyfikę etniczności berberyjskiej, podjąć próbę odpowiedzi na pytania: kim są Berberzy, jakie jest ich pochodzenie i etymologia ich egzoetnonimu. Jak zauważył już ponad ćwierć wieku temu Gabriel Camps (z pochodzenia algierski pied moir, jeden z najznamienitszych berberologów), „W rzeczywistości nie ma teraz ani języka berberyjskiego w tym sensie, że odzwierciedla społeczność świadomą swojej jedności, ani berberyjskiego ludu, a tym bardziej rasy Berberów. Co do tych negatywów wszyscy eksperci się zgadzają ... a jednak Berberzy istnieją" (Camps, 1984, s. 8).

Już w XIV wieku Ibn Chaldun (Ibn Khaldun) wychwalał lud swego pochodzenia:

Berberzy (Al-Barbar) zawsze byli potężnym ludem, groźnym, odważnym i licznym; prawdziwym ludem jak wiele innych na świecie, jak Arabowie, Persowie, Grecy i Rzymianie. [ ... ] (Obdarzeni są oni) chwalebnymi cnotami, które stanowią o czci człowieka, a które stały się ich drugą naturą [...] (są to) szlachetność duszy, która przyniosła im pierwsze miejsce wśród narodów, działania zasługujące na pochwały wszechświata, odwaga i gotowość do obrony swoich gości i klientów, wierność obietnicom, zobowiązaniom i traktatom, cierpliwość w przeciwnościach, siłę w największych nieszczęściach, łagodność, przebaczenie za winy innych, pozostawanie z dala zemsty, życzliwość dla ubogich, szacunek dla starszych i pobożnych mężów, chęć łagodzenia sporów, rzemiosła, gościnność, miłość, wielkoduszność, nienawiść ucisku, opór wobec imperiów, które im zagrażały, zwycięstwo wartości ponad dobrami doczesnymi (książętami ziemi), oddanie sprawie Bożej i religii" (Ibn Khaldun, 1852, ss. 199-200).

Pod użytym przez Ibn Chalduna terminem (Al-Barbar) kryje się zróżnicowana etnicznie rdzenna ludność Afryki Północnej i Sahary. Praberberzy zamieszkiwali od 5000 lat szeroki pas Afryki Północnej i wysp przybrzeżnych (od Wysp Kanaryjskich po granice Egiptu). Geneza tego ludu, a właściwie mówiąc grupy ludów, tak pod względem językowym, jak i rasowym pozostaje skomplikowana i ciągle tajemnicza. Stanowi do dzisiaj przedmiot sporów. Przeważa pogląd o bliskowschodnim pochodzeniu Berberów (Vicichl, 1988). Sprawę komplikuje zróżnicowanie cech fizycznych tej populacji, tak poszczególnych grup Berberów, jak i jednostek. W zasadzie nie można mówić o istnieniu "rasy” berberyjskiej. Moż- 
na sądzić, że w ciągu tysiącleci, w toku domniemanej migracji na zachód oraz w wyniku wielu najazdów i fal migracyjnych, które niosły do Afryki Północnej ludy azjatyckie (np. tureckie), jak i indoeuropejskie (np. Wandali), a także pochodzące z Afryki subsaharyjskiej (np. czarnych niewolników), wśród populacji określanej jako berberyjska nawarstwiło się wiele cech rasowych. Jak ujął to Jean Mazel, znajdujemy wśród Berberów zarówno ludzi krótkogłowych, ciemnowłosych, niskiego wzrostu, o czarnych oczach, jak i wysokich, długogłowych blondynów o oczach niebieskich (Mazel, 1975, s. 50). Nie brak też berberyjskojęzycznych osób o cechach negroidalnych - tzw. Negro-Berberów.

Od nazwy jednego ze plemion berberyjskich - Lebu, którego wojownicy wielokrotnie najeżdżali i pustoszyli zachodnie prowincje Egiptu, wywodzi się starożytna nazwa kontynentu - Libia. Z berberyjskich najeźdźców - z plemienia Meszwesz (Meshwesh) - wywodzili się faraonowie XXII dynastii (Wainwright, 1962). Berberowie stworzyli w starożytności szereg struktur plemiennych i państwowych, których nazwy pobrzmiewają do dzisiaj wśród etnonimów i toponimów Afryki. Z berberyjskich języków wywodzi się także wiele nazw odnoszących się do tego kontynentu, a nawet do odległych części świata².

Po upadku Kartaginy (na przełomie er), na terenie dzisiejszego Maroka i Algierii do dużego znaczenia doszły państwa Maurów i Numidów, które, używając dzisiejszej nomenklatury, określić można mianem „berberyjskich”. Stanowiły one zagrożenie dla rzymskich miast powstałych w tym czasie na afrykańskim wybrzeżu Morza Śródziemnego. W tym kontekście niezromanizowana ludność Afryki Północnej była po prostu ",barbarzyńcami” - barbarus, co pierwotnie w języku greckim oznaczało tyle co „cudzoziemiec”3. Można przyjąć (choć to tylko jedna z hipotez), że w ten sposób upowszechnił się uogólniający egzoetnonim rodzimej ludności tej części kontynentu - Berberzy.

Należy zaznaczyć, że źródła antyczne stosowały dla określenia pierwotnych mieszkańców rzymskich prowincji Mauritania, Tingitani (dzisiejsza centralna czéść Algierii oraz północne i zachodnie Maroko) nazwę Mazik (w różnych wariantach: Mazices, Mazaces, Mazax, Madices. Dopiero w późniejszych czasach pojawiają się też nazwy w rodzaju: Mauri, Afrił. Pod tymi nazwami kryje się nazwa ludu (ludów, rodów?), które dziś utożsamiamy z Berberami. Terminy (etnonimy) stosowane przez autorów antycznych w sposób interesujący korespondują z mitologią berberyjską. Ibn Chaldun, który - jak typowy historiograf arabski - lubił nawiązywać do biblijnego modelu genealogicznego, pisząc o (wszystkich) Berberach, stwierdził, że „ich dziadek (przodek) nazywał się Mazigh"5 (Ibn Khaldun, 1852, s. 184).

Jakby na przekór etymologii terminu „barbarzyńca”, w czasach antycznych wybitne postacie berberyjskiego pochodzenia zapisały się historii cywilizacji łacińskiej, a później wczesnochrześcijańskiej. W historiografii europejskiej wymienia się w tym kontekście

\section{......}

2 Z praberberyjskiego Maharim ( „Ci z zachodu”) bądź z maurso ('zmierzch', 'tajemniczy', ,mroczny') wywodzić się ma grecki termin Maurusia używany w odniesieniu do terenów dzisiejszego Maroka i Algierii, przeksztatcony w czasach rzymskich na 'Mauritania' (Chafik, 2005, s. 14). Stąd już blisko do łacińskiego określenia Maurus odnoszącego się do mieszkańca tej części Afryki Północnej, a także średniowiecznego 'Maura'. Od Maura z kolei pochodzi niemiecki Mohr, angielski Moor a w końcu i polski "Murzyn”, a także wiele spotykanych w Europie imion: Maurice, Moritz, Marceli. Z berberyjskiego Akal-n-lguinawen („Kraj Czarnych”) pochodzi nazwa regionu geograficznego - Zatoka Gwinejska oraz trzech państw Afryki subsaharyjskiej (Gwinei, Gwine Bissau, Gwinei Równikowej), a nawet nazwa wyspy na Oceanii - Nowej Gwinei (Paulme, 1968, s. 195).

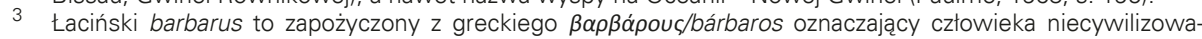
nego, mówiącego niezrozumiałym językiem, wydającego bezsensowne, niezrozumiale dźwięki: "bar-bar" (Webster's new universal unabridged dictionary, 1972, s. 149).

4 Od Afri (plemienia Afrów - żyjących na terenach dzisiejszej północnej Tunezji) wywodziła się nazwa prowincji rzymskich - Africa, później Africa Vesta, Africa Nova - powstałych na terenach zburzonej Kartaginy, a w konsekwencji też dzisiejsza nazwa całego kontynentu.

5 Zależnie od transliteracji tekstu arabskiego, tłumaczenia na języki europejskie posługują się zapisem Mazigh lub Maziy. Łacińskie litery "gh" (lub wg międzynarodowej transkrypcji fonetycznej IPA - symbol "y") oddają tu spółgłoskę płucną egresywną, czyli mówiąc obrazowo: arabsko-berberyjskie gardłowe "r". 
najczęściej cesarzy rzymskich z dynastii Severów i Gordianów oraz filozofa Tertuliana. Mniej znany jest Trentius Afer ("Afer" znaczy w tym kontekście tyle co "Afrykanin”) z II wieku przed Chr. Był to Berber porwany za młodu do Rzymu, gdzie, jako wyzwoleniec stał się dość sławnym pisarzem, tworzącym w językach greckim i łacińskim. Nie można pominąć także Arnobiusa Starszego (żyjącego w III w. po Chr.) - teologa nawróconego na chrześcijaństwo już w dojrzałym wieku (Chafik, 2005, ss. 68-69). Berberem, który wniósł największy wkład do kultury chrześcijańskiej Europy, był św. Augustyn (Aureliusz Augustyn z Hippony, łac. Aurelius Augustinus), żyjący na przełomie IV i V wieku po Ch., filozof, teolog, organizator życia kościelnego, święty Kościoła katolickiego, jeden z ojców i doktorów Kościoła 6 .

Wraz z ekspansją Arabów (który już w VII wieku rozpoczęli kolonizację północnej Afryki) desygnat terminu Berberzy (Al-Barbari, Al-Barbar, Al Berbariyya) zaczął obejmować zróżnicowane wewnętrznie, autochtoniczne ludy północnoafrykańskie definiowane przez opozycję do względnie homogennej, napływowej ludności arabskiej. W tym też okresie rozpoczął się proces arabizacji (językowej i kulturowej) mieszkańców północnej Afryki. W różnych regionach przebiegał on z odmiennym natężeniem. Niemniej, począwszy od X-XI wieku Berberzy wpisali się trwale w nurt kultury i nauki arabsko-muzułmańskiej. Współcześni Berberzy chętnie doszukują się berberyjskiego pochodzenia wielu arabskojęzycznych pisarzy, poetów, historyków lub prawników. Argumentów dostarczają im ich przydomki, w rodzaju "Sanhâdża" (od nazwy berberyjskiego plemienia), "Afer" (od plemienia Afrów), czy też "Ifriqi" - od zarabizowanej łacińskiej nazwy Africa (Chafik, 2005, ss. 68-69).

\section{JEDNOŚĆ W PLURALIZMIE}

Do końca XX wieku nie istniał jeden ogólnie przyjęty endoetnonim omawianego tu ludu. Sami Berberzy, jakkolwiek dla autoprezentacji zwykli od dawna stosować nadaną im w starożytności nazwę jako własną, jednak, zależnie od regionu, używali wiele endoetnonimów, odnoszących się raczej do poszczególnych jednostek klasyfikacji etnojęzykowej lub struktur segmentalnej struktury plemiennej. W tym drugim wypadku etnonim berberyjskiego plemienia (niezależnie od poziomu struktury segmentalnej) ${ }^{8}$ poprzedza zwykle

\section{$\cdots \cdot \cdots$}

Urodził się w Tagasie (obecnie Souk Ahras w Algierii), jako syn rzymskiego patrycjusza i matki Berberki, już wówczas zagorzalej chrześcijanki - Moniki z Hippony, też świętej Kościoła katolickiego, patronki kobiet zamężnych, zwłaszcza tych, które przeżywają kłopoty małżeńskie i nieudane małżeństwa (Bonner, 1986).

7 Średniowieczne źródła arabskie przedstawiają Al-Barbar jako „naród stawiający długi opór przeciw Arabom i islamizacji [...] oni odstępowali od prawdziwej wiary do trzynastu razy!" (Chaker, 2013). Gdy jednak w końcu ulegli, stali sie żarliwymi muzułmanami, ale w swoistej, ludowej wersji islamu, nasyconej elementami przedislamskimi. Współcześni autorzy berberyjscy podkreślają z kolei, że przez wieki pierwotna ludność północnej Afryki odrzucała narzucony im egzoetnonim, woląc stosować endoetnonimy odnoszące się do poszczególnych jednostek etnolingwistycznych bądź grup regionalnych (na przykład Berberzy z Rifu określają się jako Tarifit (I.poj. Arifi) (Encyclopédie berbère, 1986, T. 4, s. 562) [ukazało się 36 tomów Encyclopédie Berbère (obejmujących hasła od litery A do litery O)]. Można powiedzieć, że „w rewanżu” Berberzy stosowali własne, wymowne określenia w odniesieniu do Arabów, takie jak: 'Ikzam' ( „sznur”, „postronek”) lub 'Ikhamkhaman' ( „ochrypły', „szorstki”). Podczas, gdy określenie Arumi oznaczającego pierwotnie Rzymianina, zaczęło z czasem odnosić się do chrześcijan, wszystkich Europejczyków i w ogóle "obcych” (Chafik, 2005, s. 16).

8 Typowa dla Berberów i Arabów segmentalna organizacja społeczna i polityczna bazuje na unilinearnie liczonym systemie pokrewieństwa, przy czym jego system genealogiczny rozciaga się poza granice społeczności lokalnych. Funkcjonowanie tego rodzaju społeczeństw opiera się na trzech zasadach: lojalności słabnącej wraz ze wzrostem dystansu genealogicznego; zrównoważonej opozycji między segmentami; braku ustabilizowanego centralnego autorytetu. W centrum systemu segmentalnego lokuje się rodzina, a dalej pojawiają się kolejne poziomy integracji społecznej: lineaż, ród, frakcja plemienia (podplemię), plemię, konfederacja plemion (Vorbrich, 1996, ss. 149-170) 
prefiks Ait - (ber. „synowie”, „ludzie”), co w najbardziej „rzucający się w oczy” sposób odróżnia etnonimy plemion berberyjskich od plemion arabskich, poprzedzonych zazwyczaj prefiksem Beni (ar. „synowie”).

Oprócz partykularnych - plemiennych - etnonimów, w poszczególnych krajach Afryki Północnej, w odniesieniu do ludności berberyjskiej w użyciu są zarówno uogólnione etnonimy, jak i nazwy mniej lub bardziej precyzyjnie wyodrębnionych grup etnojęzykowych występujących na ich terenie. Etnograficzną i lingwistyczną strukturę ludności berberyjskiej w Afryce przedstawia Tabela 1.

Tabela 1. Struktura etnograficzna i dialektalna Berberów

\begin{tabular}{|l|l|l|l|l|l|l|l|}
\hline \multicolumn{1}{|c|}{ Kraj } & \multicolumn{1}{|c|}{ Maroko } & \multicolumn{1}{c|}{ Algieria } & \multicolumn{1}{c|}{ Tunezja } & \multicolumn{1}{c|}{ Libia } & Niger & Mauretania & Mali \\
\hline $\begin{array}{l}\text { Uogólniona } \\
\text { nazwa/ } \\
\text { etnonim }\end{array}$ & Amazigh ${ }^{9}$ & Kabyle & Amazigh & Tamacheq & Amazigh & Zenaga & $\begin{array}{l}\text { Tamajeq- } \\
\text { kidal }\end{array}$ \\
\hline $\begin{array}{l}\text { Grupy } \\
\text { etno-językowe }\end{array}$ & $\begin{array}{l}\text { Tachelhit, } \\
\text { Tamazight, } \\
\text { Tarifit, } \\
\text { Ghomara }\end{array}$ & $\begin{array}{l}\text { Kabyle, Chaouia, } \\
\text { Tamazight, } \\
\text { Hassaniyya, } \\
\text { Tumzabt, Taznatit }\end{array}$ & $\begin{array}{l}\text { Chaouia, } \\
\text { Nafusi, } \\
\text { Sened, } \\
\text { Ghadamès }\end{array}$ & $\begin{array}{l}\text { Nafusi, } \\
\text { Tamahaq, } \\
\text { Ghadamès, } \\
\text { Sawknah, } \\
\text { Awjilah }\end{array}$ & $\begin{array}{l}\text { Tamajaq, } \\
\text { Tayart, } \\
\text { Touareg }\end{array}$ & Zenaga & $\begin{array}{l}\text { Tamajaq, } \\
\text { Tamasheq }\end{array}$ \\
\hline
\end{tabular}

Źr ó d to: „Les Berbères en Afrique du Nord”, b.d.

\section{GEOGRAFIA / LICZEBNOŚĆ}

Mapa. Rozmieszczenie Berberów w Afryce Północnej

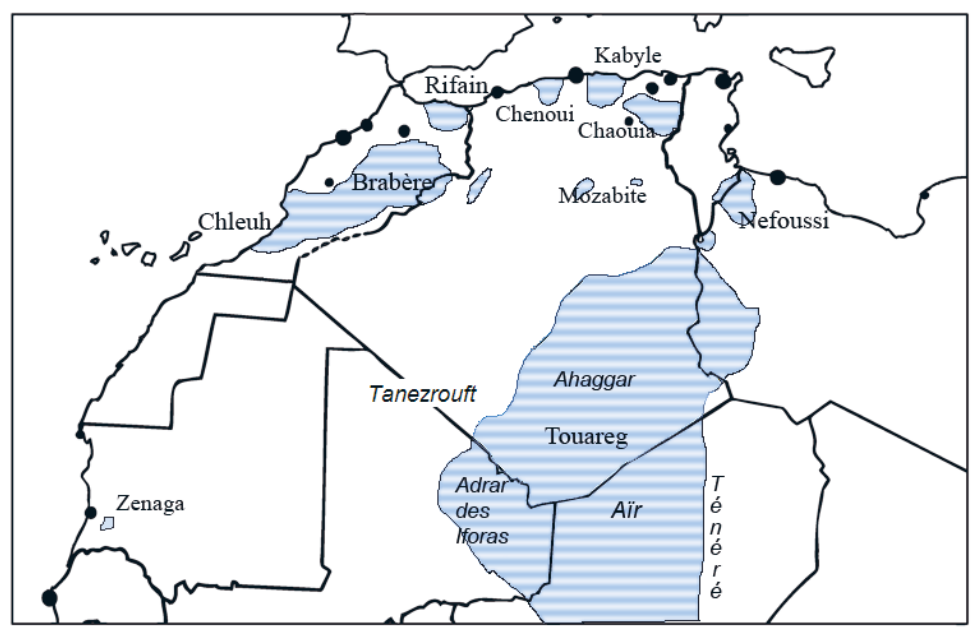

Źródło: Andries, 2006.

Tereny zamieszkane obecnie przez Berberów rozrzucone są endemicznie w kilku krajach Afryki Północnej i Zachodniej: Maroku, Algierii, Tunezji, Libii, Egiptu, Mauretanii, Mali

9 W zapisie etnonimów zachowano formę przyjętą w poszczególnych krajach. 
i Nigru. W poszczególnych krajach występują oni przemieszani w różnej proporcji wśród Arabów (i ludów zarabizowanych) oraz innych grup etnicznych (zob. Mapa).

Łączną liczbę (niezarabizowanych) Berberów szacuje się na 15-30 mln osób żyjących w krajach afrykańskich ${ }^{10}$. Szacunkowe dane dotyczące liczebności Berberów w poszczególnych krajach afrykańskich przedstawia Tabela 2.

Tabela 2. Liczebność Berberów w Afryce

\begin{tabular}{|l|c|c|c|}
\hline \multicolumn{1}{|c|}{ Kraj } & $\begin{array}{c}\text { "Berberowie" } \\
\text { https://pl.wikipedia.org/ } \\
\text { wiki/Berberowie } \\
\text { (pobrano 20.10.2018) } \\
\bullet\end{array}$ & $\begin{array}{c}\text { "Berbères" } \\
\text { http://fr.wikipedia.org/ } \\
\text { wiki/Berb\%C3\%A8res } \\
\text { (pobrano 18.03.2016) } \\
\text { Maroko* }\end{array}$ & $\begin{array}{c}\text { "Les Berbères en Afrique du Nord" } \\
\text { http://fr.wikipedia.org/wiki/ } \\
\text { Berb\%C3\%A8res } \\
\text { (pobrano 18.03.2016) } \\
\text { - }\end{array}$ \\
\hline Algieria* & 8900000 & 12000000 & $15-20000000$ \\
\hline Tunezja* & 6400000 & $7500000^{*}$ & $12-15000000$ \\
\hline Libia* & 80000 & 90000 & 100000 \\
\hline Mauretania & 470000 & $470000^{* *}$ & 220000 \\
\hline Egipt & 680000 & 680000 & 200 (!?) \\
\hline Mali & 10000 & $5000-10000$ & - \\
\hline Niger & - & $800000^{* * *}$ & $440000^{* * *}$ \\
\hline
\end{tabular}

- Wikipedia nie powołuje się na inne źródła.

- Wikipedia powołuje się na dane przytaczane przez Salema Chakera, dyrektora Centre de Recherche Berbère.

* W przypadku tych krajów należy dodać bliżej niesprecyzowaną liczbę, w różnym stopniu „zarabizowanych” Berberów, których kwota może w poszczególnych krajach sięgać nawet od 50\% do 100\% populacji Berberów podtrzymujących swą tożsamość.

* Dane odnoszą się w części do Tuaregów.

** Dane odnoszą się w zdecydowanej większości do Tuaregów.

Do tej liczby należy dodać około 1,6 mln Berberów-imigrantów, z reguły bez obywatelstwa jednego z krajów europejskich"11, zamieszkujących na stałe kraje Europy Zachodniej (w tym we Francji - 1 mln, w Hiszpanii - 250 tys., w Belgii - 200 tys. i Holandii - 150 tys.) ${ }^{12}$.

Z punktu widzenia klasyfikacji językowo-kulturowej do Berberów zalicza się często także Tuaregów, żyjących w pustynnych prowincjach kilku krajów Afryki Północnej i Zachodniej. Wielkość tej grupy ocenia się zwykle na około 1,5 mln osób (choć, jak już sygnali-

10 Liczby podawane przez samych Berberów sięgają nawet $50 \mathrm{mln}$ (Amazigh, (Berber) the indigenous non-Arab population of North Africa, and their language", b.d.). Kwestia liczebności populacji berberyjskiej jest przedmiotem nieustających kontrowersji, nie tylko z powodu labilnego charakteru ich tożsamości, ale zwłaszcza z powodów politycznych. Jeszcze w latach 80. XX w. po Ch. (gdy "kwestia berberyjska” była oficjalnie przemilczana) publikacje o charakterze naukowym szacowały populację Berberów w północnej Afryce na około $15 \mathrm{mln}$, w tym 900 tys. Tuaregów oraz 9,5 mln Berberów marokańskich i 4,5 mln Berberów w Algierii (Chaker, 1989, ss. 9-11). Ćwierć wieku później (w epoce ożywienia tożsamości berberyjskiej) ci sami autorzy szacują liczbę Berberów na ponad 24 mln, w tym 12-13 mln w Maroku i 7-8 mln w Algierii (Chaker, 2018). Szacunki zawarte w publikacjach naukowych sa zwykle nieaktualne. Dane dostepne w internecie, choć aktualne, rzadko powołują się z kolei na publikacje naukowe. Szczególnie duże rozbieżności dotyczą Tuaregów. Zależnie od źródła, ich ogólną liczbę szacuje się od 0,9 do $3 \mathrm{mln}$. Wynika to z problemów definicyjnych, pytania czy niższe kasty i niewolnicy mogą być zaliczali do tej grupy (zob. „Tamajaq, Tawallammat”, b.d.; „Tuareg people", b.d.).

11 "Liczbę tę można niemal podwoić, jeśli uwzględni się Berberów, którzy trafili do Francji z Algierii w epoce koIonialnej (jako France-musulmas) oraz osób, które opowiedziały się za Francją w algierskiej wojnie wyzwoleńczej (np. tzw. Harki - „tubylczych” żołnierzy walczących po stronie Francji ), którzy otrzymali automatycznie obywatelstwo francuskie (Vorbrich, 1996).

12 Niektóre źródła szacują liczbę Berberów w Europie na 2 lub 4 mln osób (zob. „Berbers”). Powyżej podaję liczby uśrednione z bardziej wiarygodnych źródet (por. „Berberowie” oraz "Langue française et langues de France"). 
zowałem, inne źródła podają liczbę $3 \mathrm{mln}$ ) ("Tuareg people”), w tym w poszczególnych krajach ich liczebność kształtuje się następująco: Niger - 790 tys., Mali - 450 tys., Algieria - 150 tys., Burkina Faso - 30 tys., Libia 20 tys., Maroko - 5 tys., Tunezja - 2 tys.

\section{ARABIZACJA}

W związku z problemem definiowania berberyjskości, z perspektywy antropologicznej za Berbera - a nie kogoś berberyjskiego pochodzenia - uznać można osobę, która posługuje się na co dzień językiem berberyjskim (jednym z odmian języka tamazight), ma świadomość odrębności kulturowej i językowej, choć partycypuje także (zwłaszcza w sferze oficjalnej) w uniwersalnej kulturze arabsko-muzułmańskiej. Cechami kultury berberyjskiej są poczucie dystansu do zarabizowanych instytucji i władzy centralnej. Umiłowanie niezależności przechodzi tu często $w$ skrajny indywidualizm. Stąd ich tradycyjna organizacja polityczna przybierała zazwyczaj formę republikańską, w którym władza kadencyjnych wodzów była znacznie ograniczona. Podobnie jak u Arabów, segmentarna struktura plemienna Berberów odwoływała się do ideologii pokrewieństwa, czego wyrazem były etnonimy poszczególnych segmentów plemiennych poprzedzone zwykle - jak już podkreśliłem - członem Ait („Synowie"). Symbolem dawnej niezależności i umiłowania wolności wspólnot lokalnych są rozbudowane formy budownictwa fortyfikacyjnego - niezwykłej urody ufortyfikowane wioski - ksary lub ufortyfikowane spichlerze kolektywne - agadiry (irghemy).

Ważnym czynnikiem sprzyjającym marginalizacji gospodarczej i kulturowej Berberów było zamieszkiwanie przez nich głównie w zaniedbanych gospodarczo refugialnych regionwch górskich i pustynnych. Sprzyjało to podtrzymywaniu ich tożsamości - odrębności językowej i kulturowej. W masywie Atlasu aż do lat 60. XX wieku utrzymały się enklawy czysto berberyjskojęzyczne, a do lat 90. XX wieku w wysokogórskich dolinach kobiety posługiwały się jedynie językiem (dialektem) berberyjskim.

Tradycyjną kulturę berberyjską cechuje stosunkowo wysoka pozycja kobiet, które niegdyś dostępowały nawet godności wodzowskich a do niedawna w małym stopniu zakrywały włosy, choć to się zmienito od lat 90. XX wieku, wraz z wprowadzeniem obowiązku szkolnego dla dziewcząt ${ }^{13}$. Rodziny berberyjskie są patriarchalne i monogamiczne. Tradycyjną podstawą utrzymania Berberów jest hodowla (owiec, kóz, bydła i wielbłądów) bądź rolnictwo irygacyjne na górskich tarasach. Rzemieślnicy berberyjscy słyną z produkcji biatej broni, z wyrobów ze skóry, z kobierców i biżuterii.

Sytuacja języka i kultury berberyjskiej jest zróżnicowana w zależności od kraju zamieszkania. Ulegała też pewnym zmiennym procesom, od "arabizacji” do „wtórnej berberyzacji". Proces arabizacji Berberów nie został uruchomiony automatycznie wraz podbojem arabskim i towarzyszącej mu islamizacji Afryki Północnej. Przez pierwsze wieki po podboju Arabowie stanowili niewielką liczebnie napływową warstwę mieszkańców Maghrebu. Przybysze zawierali małżeństwa z miejscowymi kobietami (dobrego przykładu dostarcza dynastia Idrysydów), dając początek nowej, mieszanego pochodzenia warstwie społecznej o wyższym statusie. Obecność tej grupy ograniczona była początkowo do przestrzeni miejskich (gdzie język arabski wspótistniał z dialektami berberyjskimi - tama-

Do połowy lat 90. XX wieku Berberki z obszarów wiejskich (zwłaszcza dziewczęta) nosiły jedynie fantazyjnie zawiązane chustki tylko częściowo zakrywające włosy. Obecnie zarówno kobiety, jak i dziewczęta szczelnie zakrywają włosy i policzki, co jest normą przekazywaną w procesie edukacji formalnej i traktowaną jako oznaka przyjęcia „kultury miejskiej” ( „wysokiej”). 
zight), a znaczna część populacji berberyjskiej, wiodącej koczowniczy lub półkoczowniczy tryb życia, była poza zasięgiem procesu arabizacji.

Arabizacja Maghrebu nasiliła się w XII wieku, gdy kolejne fale ekspansji arabskiej (przetaczające się do XVI wieku na ogromnych przestrzeniach, od Egiptu do Maroka) przerwały ciągłość obszaru etnicznego Berberów i dogłębnie zburzyły wcześniejsze układy polityczne północnej Afryki. Dekonstrukcji uległy wówczas „historyczne” potężne plemiona berberyjskie: Sanhadża, Zenata lub Masmuda (Vorbrich, 1996, s. 105). Z czasem (do XVII wieku) Arabowie, czy to w sposób bezpośredni (poprzez osadnictwo), czy też poprzez nasiloną arabizację zastanej ludności, zajęli wybrzeże śródziemnomorskie i atlantyckie i zepchnęli ludność berberyjską do izolowanych, najczęściej górskich, enklaw. Do końca XIX wieku można mówić o silnym nakładaniu się przestrzeni występowania obu języków (Boukous, 2010). Dialekty języków berberyjskich asymilowały wiele pojęć z języka arabskiego (odnoszących się do kultury wyższej i technologii), podczas gdy marokańska odmiana języka arabskiego przejęła wiele pojęć z języka (języków) berberyjskich (np. terminy z zakresu rolnictwa $)^{14}$.

Wraz z kolonizacją europejską Afryki Północnej ${ }^{15}$ pojawił się trzeci punkt odniesienia w regionalnym układzie etniczno-kulturowym - czynnik francuski (oraz w znacznie mniejszym zakresie - hiszpański). Skomplikowało to znacząco relacje arabsko-berberyjskie. Pierwotni mieszkańcy tych ziem, Berberzy, znaleźli się nie tylko pod dodatkową presją kultury i języków europejskich, lecz stali się także przedmiotem gry politycznej ze strony Francji i rodzącego się nacjonalizmu: algierskiego i marokańskiego ${ }^{16}$.

\section{PROTEKTORAT - MAROKO}

Na sytuacji Berberów epoki kolonialnej ze szczególną siłą zaważyła tzw. polityka berberyjska. Pod tym terminem kryje się chwiejna doktryna i praktyka władz protektoratów (Maroka i Tunezji) oraz Algierii względem pierwotnej warstwy osadniczej Afryki Północnej. Ta „polityka berberyjska” nabrała szczególnego znaczenia politycznego w Maroku. W tym kraju, o najliczniejszym komponencie berberyjskim, narzucenie zwierzchnictwa Francji oznaczało bowiem zarazem faktyczne i ostateczne podporządkowanie, terytoriów peryferyjnych (górskich i pustynnych) władzy centralnej ${ }^{17}$. W czasach przedkolonialnych z powodu niewydolności państwa, peryferyjnie położone ziemie Berberów cieszyły się względną swobodą. Był to obszar w różnym zakresie kontestujący władzę sułtanów marokańskich - tzw. Bled es Siba („kraj Iwa”) ${ }^{18}$. Pacyfikacja (prowadzona w praktyce rękoma Francuzów) spowodowała objęcie ostatnich ostoi kultury berberyjskiej kontrolą państwa. Wpływ „arabskiego" państwa zaznaczył się najsilniej w trzech podstawowych sferach: prawa,

\section{......}

14 Z kolei słownictwo morskie Berberów pochodzi z języka hiszpańskiego, a techniczne z francuskiego (Boukous, 1989, ss. 5-18; Chafik, 2005, s. 78).

15 Której umowne daty graniczne w poszczególnych krajach Maghrebu były różne (Algieria 1830/1847-1962, Maroko 1912-1956, Tunezja 1881-1956, Maroko 1912-1956).

16 W wypadku Libii i Egiptu, z racji niewielkiej liczebności populacji berberyjskiej, jej znaczenie polityczne było mało istotne. Odmienna sytuacja rozwinęła się we Francuskiej Afryce Zachodniej (na terenach obecnej Mali i Nigru), gdzie relacje w trójkącie Tuaredzy - Arabowie - Francuzi wzbogacone były przez kolejny czynnik ludy subsaharyjskie.

17 Nominalnie władzy sułtana, w praktyce zaś administracji sprawowanej przez Francuzów (gubernatora generalnego). W terenie kluczową rolę w „polityce berberyjskiej” odegrało Biuro do Spraw Tubylców (Bureau des Affaires Indigènes), które wytyczało kierunki polityki względem ludności tubylczej Maroka.

18 W opozycji do tzw. Beled el makhzen („ziemie państwa”) terytorium, na którym na co dzień uznawano władzę sultana. 
edukacji i religii. Jurysdykcja na ziemiach berberyjskich przeszła w ręce terenowych funkcjonariuszy makhzenu'19, kaidów (odpowiednik starostów) i kadich (sędziów koranicznych). Posuwali się oni często za pacyfikującą Berberów armią francuską i narzucali stosowanie języka i prawa Koranu. Wywoływało to konflikty w terenie. Francuzi starali się zneutralizować opór Berberów, stosując szereg metod określanych właśnie mianem „polityki berberyjskiej'. Mówiąc w dużym uproszczeniu, sprowadzała się ona do oddzielenia Berberów od Arabów w sferze społecznej i prawnej. Podejmowano (mało skuteczne) działania mające na celu chrystianizację ludności berberyjskiej. W administracji francuskiej panowało przekonanie o powierzchownej islamizacji Berberów i szansach na „wykorzenienie wśród nich śladów kultury islamu i uczynienia z Berberów Europejczyków" (Bremond, 1950; Halstead, 1967, s. 71)20. Już w 1914 roku wydano prawo (dahir) uznające zwyczajowe prawo berberyjskie. Z czasem powołano sądy prawa zwyczajowego pierwszej i drugiej instan$\mathrm{cji}^{21}$. Jeszcze dalej poszedł kolejny dekret - tzw. dahir berberyjski z 1930 roku. Wyłączał on prawie wszystkie plemiona uznane przez administrację za "berberyjskie” spod kontroli szaria i poddawał je jurysdykcji sądów prawa zwyczajowego. Dahir berberyjski odzwierciedlał zwrot w polityce protektoratu, która zamiast, jak poprzednio, utrzymywać równowage między Arabami a Berberami, zmierzała do zasymilowania tych ostatnich ze społeczeństwem i kulturą Francji. Celowi temu miały służyć przepisy separujące berberyjskich górali od ich arabskich sąsiadów z dolin. Wstęp do regionów górskich (berberyjskich) został ograniczony tylko do osób posiadających paszport i specjalne pozwolenie.

Istotnym elementem „polityki berberyjskiej”, mającej przeciwdziałać arabizacji młodego pokolenia Berberów (poddanemu obowiązkowi szkolnemu), było stworzenie jeszcze w latach 20. XX wieku sieci szkół franko-berberyjskich. Szkolnictwo tego typu było dwustopniowe, z tzw. college berbére jako zwieńczeniem edukacji. Ulokowana w Azrou (u stóp Średniego Atlasu, jądrze berberyjskiego obszaru etnicznego) szkoła ta stała się centrum propagandy rodzącego się nacjonalizmu berberyjskiego, kuźnią berberyjskiej inteligencji doby Protektoratu22.

Polityka berberyjska wywołała wzburzenie u arabskiej części społeczeństwa marokańskiego. Berberom przypięto „łatkę" separatystów, która wykorzystywana była przeciwko nim także później, w niepodległym Maroku. Marokańska opinia publiczna traktowała opisane posunięcia władz Protektoratu, zwłaszcza "dahir berberyjski”, jako złamanie traktatu feskiego z 1912 roku, którego art. I gwarantował obronę religii muzułmańskiej (Urząd ds. Religii był jedynym ministerstwem w rządzie marokańskim niepodlegającym gubernatorowi francuskiemu a bezpośrednio sułtanowi). Uderzenie w ostatni bastion suwerenności makhzenu dało w konsekwencji impuls do rozwoju nowoczesnego nacjonalizmu marokańskiego, który doprowadził po ćwierćwieczu do odzyskania niepodległości przez Maroko. Po 1956 roku, w następstwie odzyskania niepodległości przez Maroko, dynamika

19 Makhzem (po arabsku „magazyn”) oznaczał w średniowiecznym Maroku skrzynię, magazyn, w którym przechowywano skarbiec sultański (w późniejszym okresie także armaty). W literaturze przedmiotu termin ten odnosi się do tradycyjnych, przesiąkniętych nepotyzmem struktur monarchii marokańskiej (Vorbrich, 1996, ss. 262-271).

20 Pojawiały się opinie, że „Berberzy są mniej próżni niż Arabowie, mniej przesiąknięci poczuciem wyższości w stosunku do chrześcijan [...] będą uczniami bardziej pojętnymi [...] zmuszeni do nauki obcego języka, niech uczą się francuskiego a nie arabskiego. Niech staną się francuskojęzyczni a nie arabskojęzyczni" (Bernard \& Moussard, 1924, s. 282).

21 Towarzyszyły temu działania (Biura do Spraw Tubylców) polegające na zbieraniu, kodyfikowaniu i publikowaniu norm prawa zwyczajowego (Halstead, 1967).

22 Należy jednak zaznaczyć, że - jak mogłem się przekonać osobiście - działalność szkół franko-berberyjskich jest źle oceniana przez współczesne elity berberyjskie. Zwracają one uwagę, że w dobie Protektoratu nie podjęto inicjatywy mającej na celu stworzenia pisma berberyjskiego lub berberyjskiej prasy. Powstałe $w$ tym czasie studia berberystyczne nie wyszły poza wąskie grono akademickie. 
procesów politycznych i kulturowych zahamowała lub wręcz zastopowała na pewien czas rozwój nowoczesnej tożsamości Berberów marokańskich.

\section{W ALGIERII FRANCUSKIEJ}

Algierscy Berberzy, w tym najliczniejszy ich odłam - Kabylowie ${ }^{23}$ do początku XIX wieku stanowili w tym kraju ludność drugiej kategorii. Kulturowo dominowali tu Arabowie, a politycznie (od XVI wieku) Turcy ${ }^{24}$. Począwszy od 1830 roku, a zwłaszcza od upadku powstania Abdel el-Kadera (1847), obszary etniczne algierskich Berberów stały się integralną częścią Francji25. Dla ludności berberyjskiej (zaludniające wcześniej zmarginalizowane regiony górskie północnej Algierii) oznaczało to awans ekonomiczny, społeczny i kulturowy. Ziemie berberyjskie stały się rolniczym zapleczem rozwijających się aglomeracji wybrzeża (Oranu, Algieru, Jijel, Collo i Annaby), co przyczyniło się do rozwoju gospodarki towarowej, wzrostu stopy życiowej oraz przyjęcia pewnych wzorów kultury europejskiej. Jednym z takich elementów kultury europejskich był ruch skautowy, rozwijający się od lat 40. XX wieku się wśród młodego pokolenia Kabylów. W ramach tego ruchu zrodził się nowoczesny nacjonalizm berberyjski, nawiązujący do idei oświeceniowych. Śpiewana przez uczestników kabylskiego ruchu skautowego nowa pieśń „Powstańcie synowie Berberii" (Ekker a mmis umazigh) stała się po 50 latach hymnem Berberów Afryki Północnej. W tejże pieśni pojawił się po raz pierwszy neologizm Umazur (Amazigh), później uznany za endoetnonim wszystkich Berberów (Chaker, 2013).

Od początku swego panowania Francuzi wykorzystywali Berberów w swojej polityce podboju. Najgłośniejszym tego przykładem jest formacja piechoty górskiej - tzw. Żuawów (nazwa ta pochodzi od plemienia berberyjskiego Zuawa), którzy uczestniczyli w podboju południowych regionów Algierii, a w XX wieku walczyli „za Francję” w Europie i w Indochinach. Tradycje kolaboracji z władzami francuskimi kontynuowało wielu Berberów podczas tzw. wojny algierskiej (wojny o niepodległość Algierii z lat 1954-1962). W wyniku decyzji gen. Charles'a de Gaulle'a, który przyznał niepodległość Algierii (jak już zaznaczyłem, integralnej części Republiki Francuskiej), algierscy Berberzy zostali poddani fali represji. Dotyczyło to osób, które walczyły po stronie sił rządowych, jako zwykli rekruci, a zwłaszcza członków formacji pomocniczych i specjalnych: Force auxiliare franco-musulmane (FARM), tzw. komand myśliwskich (Comandsos de Chasse) i grup samoobrony (Groupes d'autodéfense - GAD), broniących własnych wiosek przed atakami partyzantów z Armii Wyzwolenia Narodowego (Armée de Libération Nationale - ALN) - zbrojnego ramienia FLN26.

23 Pod pojęciem Kabyle (Kabylowie) kryje się zespół plemion. Nazwa ta jest egzoetnonimem (od arabskiego al-kabajel - „plemiona'), który dobrze oddaje marginalizację Berberów w przedkolonialnym społeczeństwie Algierii. Sami Kabylowie określają siebie mianem Leqbayel.

24 Do XIX wieku warstwą panująca w Algierii (jej północnej części) byli tzw. Kugulowie - ludność pochodzenia turecko-arabskiego.

25 Należy w tym miejscu zaznaczyć, że od początku we francuskim dyskursie kolonialnym oraz doktrynie prawnej „tubylcy” w Algierii stawali się obywatelami francuskimi, ale zarazem w praktyce wyraźnie rozróżniano status różnych kategorii „tubylców”: Arabów, Kabyłów, Mozabitów i Żydow (Izraelitów) (Bachmann, 1894; Leimdorfer, 1984).

26 Liczebność sił pomocniczych i specjalnych, złożonych z "tubylców" („muzułmanów”), szacowana była przez władze francuskie na 180 tys. Obecnie uważa się, że była ona zawyżana ze względów propagandowych i można ją określić na 162 tys. (Ageron, 1995, s. 10). 
Po wycofaniu się Francji z Algierii ludzie, którzy opowiedzieli się za "Algierią francuską", znani pod ogólną nazwą Harki (ar. "ruch"), musieli (często w dramatycznych okolicznościach) opuścić w 1962 roku swe wioski i szukać schronienia we Francji. Ocenia się, że około 91 tys. Harki (wraz z rodzinami) emigrowało wówczas do Francji, tworząc bazę rozwijającego się na emigracji nacjonalizmu berberyjskiego.

Z tych, którzy pozostali w Algierii, zamordowano (często w bestialski sposób), według różnych szacunków, od 30 tys. do 150 tys. osób27. W niepodległej Algierii te krwawe represje, stały się tematem tabu i na pewien czas zahamowały rozwój oficjalnych berberyjskich ruchów nacjonalistycznych. Zarazem jednak stanowią one do dzisiaj niezatarty element pamięci zbiorowej współczesnych Berberów algierskich.

$\mathrm{Na}$ tej zbiorowej pamięci i poczuciu wspólnoty przekraczającej granice niepodległej Algierii i Maroka, ale i w ramach diaspory rozsianej w Europie (głównie we Francji. Belgii i Holandii), po latach walki z proarabskim nastawieniem swych rządów rozwinął się tak zwany ruch berberyjski. Wielkim wysitkiem rewitalizowano i unifikowano język tamazight, upowszechniono staroberberyjski alfabet - tinafagh. W końcu doprowadzono do uznania języka i kultury berberyjskiej (Amazigh) za istotny komponent tożsamości mieszkańców Algierii i Maroka ${ }^{28}$.

\section{BIBLIOGRAFIA}

Ageron, C.-R. (1995). Les supplétifs algériens dans l'armée française pendant la guerre d'Algérie. Vingtième Siècle: Revue d'histoire, 1995(48), 3-20. https://doi. org/10.2307/3770209

Amazigh, (Berber) the indigenous non-Arab population of North Africa, and their language. (b.d.). Pobrano 18 marca 2016, z https://phoenicia.org/berber.html

Andries, P. (2006). Grandes aires linguistiques berbérophones. W Wikipedia. Pobrano z https://commons.wikimedia.org/wiki/File:Grandes-aires-linguistiques-berb\% C3\%A8res -v2.png (9.10.2014)

Bachmann, P. (1894). De la condition des personnes en Algérie (en Droit Francçais). Nancy. Bonner, G. (1986). St Augustine of Hippo: Life and controversies. Norwich: Canterbury Press.

Berbères. (b.d.). W Wikipédia. Pobrano 15 maja 2016, z http://fr.wikipedia.org/wiki/ Berb\% C3\%A8res (18.03.2016)

Les Berbères en Afrique du Nord. (b.d.). Pobrano 20 września 2018, z http://www.axl. cefan.ulaval.ca/afrique/berberes_Afrique.htm

Berberowie. (2018). W Wikipedia. Pobrano 20 września 2018, z https://pl.wikipedia.org/ wiki/Berberowie

Berbers. (2017). W LookLex Encyclopaedia. Pobrano 11 maja 2017, z http://looklex.com/ e.o/berbers.htm

27 Wielu zginęło (lub zostało okaleczonych), gdy zmuszano ich do oczyszczania pól minowych. Inni byli torturowani, kastrowani przed śmiercią (kazano im połknąć własne genitalia), spaleni żywcem, poćwiartowani i rzucani psom na pożarcie. Wielu zabito wraz z rodzinami (i małymi dziećmi). Wydarzenia te przeszły do historii pod nazwą „dzikiej wojny o pokój” (Horney, 2006).

28 Walka ta była niekiedy krwawa (zwłaszcza w Algierii), ale doprowadziła do konstytucyjnego uznania języka berberyjskiego (tamazight) za język oficjalny w Maroku (Konstytucja z 2011 r.) i w Algierii (projekt Konstytucji ogtoszony w 2016 r.). 
Bernard, A., \& Moussard, P. (1924). Arabophones et berbérophones au Maroc. Annales de Géographie, 33(183), 267-282. https://doi.org/10.3406/geo.1924.9671

Boukous, A. (1989). L'emprunt linguistique en Berbère: Dependence et crétivite. Etudes et Documentes Berbères, 6, 5-18.

Boukous, A. (2010). Revitalisation de la langue amazighe: Defis, enjeux et strategies. Rabat: IRCAM.

Bremond, G. (1950). Berbéres et Arabes: La berbérie est un pays européen. Paris: Payot.

Camps, G. (1984). Avertissement: Être berbère. W Encyclopédie berbère (T. 1, ss. 6-48). Aix-en-Provence: IREMAM.

Chafik, M. (2005). A brief survey of thirty-three centuries of Amazigh history. Rabat: IRCAM.

Chaker, S. (1989). Berbères aujourd'hui. Paris: Harmattan.

Chaker, S. (2013). Amazigh / Berbère / Tamazight : dans les méandres d'une denomination. Revue des Études Berbères, 9, 221-239

Chaker, S. (2018). Langue et littérature berbères. Pobrano 15 czerwca 2018, z http:// www.clio.fr/BIBLIOTHEQUE/langue_et_litterature_berberes.asp

Halstead, J. (1967). Rebirth of a nation: The origins and rise of Moroccan nationalism, 1912-1914. Cambridge, MA: Center for Middle Eastern Studies.

Horney, A. (2006). A savage war of peace: Algeria 1954-1962. New York, NY: New York Review Books Classics.

Ibn Khaldun. (1852). Histoire des Berbères et des dynasties musulmanes de l'Afrique Septentrionale (1378) (T. 1) (Baron de Slane, Tłum.). Alger: Imprimerie du Gouvernement.

Langue française et langues de France. (b.d.). Pobrano 20 września 2018, z http://www. dglflf.culture.gouv.fr/lgfrance/lgfrance_presentation.htm

Leimdorfer, F. (1984). Condition des indigenes dans I'Algérie colonial: Essai d'analise socio-linguistique a partir des titres de theses soutenues pendant la période colonialne. W J.-C. Vatin et al., Connaissances du Maghreb: Sciences Sociales et Colonisation (ss. 185-212). Paris: CNRS.

Mazel, J. (1975). Zagadki Maroka (A. Steinsberg, Tłum.). Warszawa: PIW.

Paulme, D. (1968). Gunée. W G. Balandier \& J. Maquet (Red.), Dictionaire des civilisation africaines (s. 195). Paris: F. Hazan Editeur.

Tamajaq, Tawallammat. (b.d.). Pobrano z https://www.ethnologue.com/language/ttq

Tuareg people. (2017). W Wikipedia. Pobrano 14 czerwca 2017, z https://en.wikipedia. org/wiki/Tuareg_people

Vicichl, W. (1988). Les Imazghen, 5000 ans d'histoire. Etudes et documents berbéres, 4, 85-93.

Vorbrich, R. (1995). Franco-Maghrebins: Muzułmanie z Maghrebu w Europie Zachodniej. Sprawy Narodowościowe: Seria nowa, 4(1(6)), 97-115.

Vorbrich, R. (1996). Górale Atlasu marokańskiego: Peryferyjność i przejawy marginalności. Wrocław: PTL.

Wainwright, G. (1962). The Meshwesh. Journal of Egyptian Archæology, 48, 89-99. https:// doi.org/10.2307/3855788

Webster's new universal unabridged dictionary. (1972). New York, NY: Simon and Schuster Publishing. 